\title{
Biology and ecology of Elatophilus nigricornis Zetterstedt (Hemiptera Anthocoridae) predator of Matsucoccus feytaudi Ducasse (Homoptera Matsucoccidae) in the South-East of France
}

\author{
Jean-Pierre Fabre, ${ }^{\mathrm{a},}$, Pierre Menassieu ${ }^{\mathrm{b}}$, Jean-Jacques Foing ${ }^{\mathrm{a}}$ and Alain Chalon ${ }^{\mathrm{a}}$ \\ a Unité de Recherches Forestières Méditerranéennes, INRA, av. Vivaldi, 84000 Avignon, France \\ ${ }^{\mathrm{b}}$ Laboratoire d'Entomologie Forestière, INRA, Pierroton BP 45, 33611 Gazinet Cedex, France
}

(Received 23 December 1999; accepted 26 May 2000)

\begin{abstract}
The pine scale Matsucoccus feytaudi was accidentally introduced into the maritime pine stands of the Maure and Estérel Forests. It is the primary cause of the dieback of 120000 ha stands and its specialist predator Elatophilus nigricornis has been studied. It is possible to maintain and raise it in laboratory conditions but its output is not prolific enough to envisage propagation which would allow it to be released in natural conditions. When raised in laboratory conditions the time required for its development (table II) and fecundity have been determined. In natural conditions, nymphs develop in trunk bark cracks, adults mate, but females insert eggs in needles. The population of the eggs is distributed according to two gradients: a decreasing gradient from the bottom to the top of the trees and a decreasing gradient from the trunk to the extremities of the branches (figures 3 and 4). The distribution of its nymph populations on the trunk and branches is different before (figure 5) and after (figures 6 and 7) the invasion of M. feytaudi. In reality, the distribution of the predator nymph populations always coincides with that of its host even when that of the latter changes. E. nigricornis produces at least three generations a year (one for $M$. feytaudi) and overwinters at the fertilized female stage (figures 1 and 2). Two sampling methods have allowed us to estimate the population levels which have developed during (figure 8 ; table III ; $I V$ ) and after the pine scale invasion (figures 9 and 10, table V). Even when there was widespread destruction of the trees attacked due to the action of the xylophagous, there is a link between the size of the E. nigricornis populations on the trees and the capacity of the tree to survive. In stands where more than half the trees survived it was found that in 6 years the level of weekly captures was multiplied by 26 (figure 9). Finally, on regeneration trees which replaced the old stands that had been destroyed or felled, the population levels are 3 times greater (figure 10).
\end{abstract}

Elatophilus nigricornis / predator / bioecology / population dynamics / Matsucoccus feytaudi / Pinus pinaster

Résumé - Biologie et écologie d'Elatophilus nigricornis Zetterstedt (Hemiptera Anthocoridae) prédateur de Matsucoccus feytaudi Ducasse (Homoptera Matsucoccidae) dans le Sud-Est de la France. Les pullulations de la cochenille Matsucoccus feytaudi, introduite accidentellement dans les peuplements de pins maritimes des Maures et l'Estérel, ont entraîné le développement de son prédateur Elatophilus nigricornis. Il est possible de maintenir E. nigricornis en élevage au laboratoire mais son rendement ne permet pas d'envisager sa multiplication pour effectuer des enrichissements dans les conditions naturelles. La durée de son développement et sa fécondité ont été précisées. Sur le terrain, il vit dans les fissures des écorces des troncs et des branches. Les femelles déposent ses œufs dans les aiguilles. La répartition de ses pontes est décrite et interprétée. Il présente trois générations par an, alors que M. feytaudi n'en a qu'une, et passe l'hiver au stade de femelle fécondée. Deux méthodes d'échantillonnage ont permis d'estimer ses populations : elles sont en très bonne coïncidence spatiale avec celles de son hôte ; même quand la répartition de ce dernier sur l'arbre

* Correspondence and reprints

Tel. (33) 04901359 22; Fax. (33) 04901359 59; e-mail: fabre@avi-forets.avignon.inra.fr 
change ; elles sont plus élevées sur les arbres survivants et surtout sur les arbres issus de régénérations naturelles qui se sont développés après la destruction des peuplements initiaux. En définitive E. nigricornis est un prédateur sur les pins très spécialisé sur Matsucoccus.

Elatophilus nigricornis / prédateur / bioécologie / dynamique des populations / Matsucoccus feytaudi / Pinus pinaster

\section{INTRODUCTION}

Matsucoccus feytaudi is a pine scale specific to maritime pine Pinus pinaster Soland in Ait., wide-spread in the west of the Mediterranean area, where it is endemic. Its introduction into the South-East of France is at the origin of the rapid multiplication of xylophagous which brought about the dieback of at least 120000 ha of forest in the Maures and Estérel areas [4, 12, 33, 35, 36]. The damage it caused then continued into the north of Italy $[10,14]$. It is now to be found in Corsica [17] where the first signs of dieback are appearing on maritime pine [18].

No parasitoid has ever been found on the genus Matsucoccus. However, several significant Anthocoridae predators belonging to the genus Elatophilus are known to be associated with other Matsucoccus species which are also very harmful: E. inimicus Drake \& Harris and $M$. resinosae Bean \& Godwin on $P$. resinosa Ait. in Connecticut (U.S.A.) [19]; E. nipponensis Hiura and M. matsumurae Kuwana on P. massoniana Lambert and $P$. tabulaeformis Carrière in the east of China [6, 7, 27]; E. hebraicus Péricart and M. josephi Bodenheimer \& Harpaz on P. halepensis Mill. and P. brutia Ten. in Israel, Jordan, Lebanon, Turkey Cyprus, Crete [2, 5, 23, $25,30]$.

On M. feytaudi, in the Maures and Estérel areas, more than 13 species of predatory insects or arachnida have been definitely identified thanks to immunochemical techniques [15]. In Liguria and Tuscany 12 species of insects have been indexed, three of which belong to the genus Elatophilus [9].

In 1967 the predator Elatophilus nigricornis, identified by J. Carayon (Muséum d'Histoire Naturelle, Paris) was observed for the first time in the Maures area (N.D. des Anges). The identification was confirmed by J. Péricart (personal communication, 1990), on specimens from several localities in the Maures and Estérel areas. Due to its constant presence and the considerable size of its populations this species has proved to be the main predator of pine scale where it has been introduced: in Provence, near San Rémo [14] and in northern Italy [9]. It has also been found everywhere that M. feytaudi existed in an endemic state: in the Landes of Gascony
[32], in the Gard (Bessèges and Bouzigues), in the Ardèche (Les Vans), in Spain, in the Sierra de Guadarama (Mission Riom, 25.10.1968), in Morocco (Mission Fabre \& Riom), in the Middle-Atlas (forest of Tamrata 18.11.1971) and in the Rif (forest of Tétouane and Talassemtane 20.11.1971).

E. nigricornis has been observed on other pine: Pinus sylvestris L. in Great Britain [34] and at Fontainebleau [28]; Pinus pinea L. [29]; Pinus halepensis in Israel [30]. It is also the predator of Matsucoccus pini Green on Pinus nigra Arnold, on Mont Ventoux (ssp. austriaca (Höss)) [31], in Corsica (ssp. laricio Poiret) in the forests of Aitone, Bavella and Valdo Niello (Mission Fabre, 06.1976), in Italy [9] in Tuscany (ssp. Laricio) in the Abruzzes (ssp. Italica Hochstetter).

Knowledge concerning the bioecology of E. nigricor$n i s$ is scarce in the present literature: nymphal stages, eggs, oviposition and laying on Scots pine in Great Britain [34], geographical distribution [29], biological characteristics on maritime pine in Italy [9]. The aim of this article is to review the current state of research which has been carried out on this insect from 1967 onwards and during the progression of pine scale from Maures towards Estérel: its biology, life cycle, distribution and population size, with particular reference to their incidence on those of pine scale. In the laboratory, experiments were carried out concerning the possibility of rearing E. nigricornis with a view to releasing them into natural conditions (biological control).

\section{MATERIALS AND METHODS}

\subsection{Laboratory rearing trial}

Several experiments were carried out in which E. nigricornis (larvae and/or adults) were placed next to fresh maritime pine needles, on which the females lay their eggs. These trials were carried out in ventilated transparent polystyrene boxes or in Rhodoid cages. Before, so as to maintain a favourable level of relative humidity, a layer of plaster between 0.5 and $1 \mathrm{~cm}$ thick or a layer of "green foam" as used by florists was placed 
on the bottom of the boxes. In both cases they were moistened at regular intervals. Several rearing accessories were used:

1. Cut maritime pine needles, placed horizontally in a cylinder-shaped box $($ diameter $=105 \mathrm{~mm}$, height $=$ $20 \mathrm{~mm}$ ).

2. Needles planted vertically in "green foam" in a parallelepipedic box (length $=85 \mathrm{~mm}$, width $=55 \mathrm{~mm}$, height $=43 \mathrm{~mm}$ ).

3. A maritime pine branch the base of which was inserted into a rubber balloon full of water placed horizontally in a parallelepipedic box (length $=260 \mathrm{~mm}$, width $=130 \mathrm{~mm}$, height $=77 \mathrm{~mm}$ ).

4. A maritime pine branch placed vertically into a cylinder-shaped box (diameter $=115 \mathrm{~mm}$, height $=$ $230 \mathrm{~mm}$ ) made up of 3 interlocking parts. The bottom part contained water in which the base of the branch was soaked. The middle one allowed the stem of the branch to protrude and had a layer of plaster to hold it in place. The top part had a cap on it.

5. A potted maritime pine plant between 3 and 4 years old watered by capillary attraction and covered by a rearing cage made of rigid transparent plastic (height $=0.65 \mathrm{~m}$, width $=0.30 \mathrm{~m}$ ) closed at the top with nylon netting.

The predators were fed on the eggs of a substitute host, the flour moth Anagasta kuehniella Z. Mass rearing in order to obtain these eggs has already been described [11]. Using a brush, they were stuck onto a sheet of squared white paper (width $=10 \mathrm{~mm}$ ) with water. Then, each week, a certain number of "squares" were cut out and placed in the bottom of the rearing boxes with the surface containing the eggs facing downwards, thus providing the Anthocoridae with individual shelters and partly avoiding cannibalism. In addition, experiments were carried out with A. kuehniella caterpillars in a seminatural diet made from hen egg yolk presented in the form of globules covered with paraffin (1 to $10 \mathrm{~mm}$ ), or, preferably, in a film of "M parafilm" (made by Marathon products, USA). In addition, laying trials were carried out on needles from different types of conifers. Finally, these trials were attempted with a completely artificial laying support made out of transparent polystyrene stems 1-3 mm square covered with "M parafilm".

The rearing boxes were placed in a controlled environment chamber with a programmed daily temperature of $13-20{ }^{\circ} \mathrm{C}$ and 16 hours of light.

\subsection{Population sampling}

Two techniques for taking samples of natural populations of E. nigricornis in situ were used. In certain conditions the same techniques permitted the sampling of M. feytaudi.

\subsubsection{Direct counting}

This technique is applicable in the case of a felled tree, either with reference to the trunk, cut into pieces of a given length, say $1 \mathrm{~m}$, or to the branches of the crown. The material is placed in a lethal chamber made up of a Plexiglass cylinder measuring 1.20 by $0.35 \mathrm{~m}$ which allows the introduction of carbonic gas for 20 to $30 \mathrm{sec}-$ onds. This is left to take effect for 2 to 10 minutes. The trunk sections are then taken out and struck vigorously in the middle with a cone which has a metal part. The branches are shaken vigorously. In this way Elatophilus nymphs and adults can be collected [1]. This technique was used on 359 trees in 9 sites (table I). In addition, on 01.10.1969 and 16.10.1969 we examined 46 trees at different stages of dieback: 12 with no external symptoms: class 0,12 with some slight symptoms: class 1,12 with symptoms on half the crown: class 2,10 with $2 / 3$ of the crown withering: class 3 . In addition, on each tree we took $10 \mathrm{~cm}$ samples from the trunk (at heights of: $0.90-1.00,1.90-2.00,2.90-3.00 \mathrm{~m}$ ) and by studying

Table I. Use of the direct method of counting on 359 trees, in 9 stations of the Maures and l'Estérel.

\begin{tabular}{lccc}
\hline Station & Altitude & Dates & Frequency \\
\hline les Dramonts & $10 \mathrm{~m}$ & from 24.01.1968 to 07.08.1968 & 5 times \\
les Campaux & $50 \mathrm{~m}$ & from 11.04.1968 to 18.12.1969 & 8 times \\
la Bouverie & $100 \mathrm{~m}$ & from 09.07.1969 to 21.10.1971 & 12 times \\
Malpasset & $100 \mathrm{~m}$ & from 14.04.1968 to 04.12.1968 & 5 times \\
les Cannebières & $130 \mathrm{~m}$ & from 24.04.1968 to 18.09.1969 & 9 times \\
le Rouet & $190 \mathrm{~m}$ & 09.07 .1968 & 1 times \\
Forcalqueiret & $300 \mathrm{~m}$ & from 20.08.1968 to 03.04.1969 & 1 times \\
le Treps & $550 \mathrm{~m}$ & from 13.09.1967 to 19.12.1968 & 9 times \\
Notre Dame des Anges & $630 \mathrm{~m}$ & 17 times & $3-10$ \\
\hline
\end{tabular}


these samples under a magnifying glass in the laboratory we determined the number of M. feytaudi at the second larval stage.

\subsubsection{Indirect counting}

This technique is applicable in the case of trees in natural conditions. It consists of placing a light brown selfadhesive tape, made out of PVC, $50 \mathrm{~mm}$ wide, round the trunk, at a height of $1.50 \mathrm{~m}$. The adhesive surface is applied to the bole and a double thickness of tape is placed on top of it, which allows it to maintain its adhesive properties for more than a month. The tapes are removed each week and immediately stuck onto a film of transparent polyethylene. The material is brought back to the laboratory and stored in the freezer. The samples are then counted by means of a binocular lens. This type of trap captures the nymphal stage and the adult of E. nigricornis and the mobile stages of M. feytaudi. This technique was used between 03.1975 and 07.1979 at 3 sites:

- La Môle (83), in the Maures, at an altitude of $50 \mathrm{~m}$, on 21 trees, 10 years old in 1975, 3-4 m in height, regenerating after clear felling of an adult stand partly destroyed by the invasion of $M$. feytaudi and xylophagous.

- Lambert (83), in the Maures near Collobrières, at an altitude of $500 \mathrm{~m}$, on 21 trees similar to the previous site.

- Villeneuve-Loubet (06), in the Estérel, in the Vaugrenier park, on the coast (altitude of $10 \mathrm{~m}$ ), on 44 trees, between 7 and $8 \mathrm{~m}$ high, about 25 years old, which were in the process of being severely attacked by pine scale and xylophagous.

It was also used in other areas where the pine scale lives is endemic: in the Landes, at a site near Bordeaux known as the Lagune du Merle, from 30.12.1976 to 23.06.1977, on 20 trees and at Pierroton, a site next to the previous one, on 30 trees from 01.03.1978 to 08.06.1978; in the department of the Ardèche at Vans, on 20 trees, from 20.12.1976 to 13.12.1977 and in 4 stands in the department of the Gard. Finally, the method was used on a tree in a regeneration area at Ruscas (83) from 31.08.1977 to 31.05.1978. In this case, adhesive tapes were placed on the trunk between each verticil and on the branches approximately $25 \mathrm{~cm}$ from the trunk.

In addition, a further method of indirect counting consists of stapling on to the trunk strips of double-slotted corrugated cardboard covered with two flat surfaces, one made out of kraft paper, the other of greaseproof paper placed against the trunk. This type of trap is used to capture the $M$. feytaudi [3] females. We were thus able to capture living specimens of E. nigricornis larvae and adults as well as the other pine blast predators [15]. It was also used for the capture and transport of E. nigricornis to the USA.

\subsubsection{Laying sampling}

This study, carried out at La Bouverie (83), involved a detailed examination of several crowns. These were collected, brought back to the laboratory and stored in the freezer. Each needle was examined visually and then the number of eggs was established by means of a binocular lens with slight magnification. A first crown of $2.90 \mathrm{~m}$ from a tree $4.60 \mathrm{~m}$ in height was examined on 26.03.1970 in three sections. A more detailed examination was carried out 26 and 28.05.1970 on 3 trees of $5.15,4.75$ and $4.00 \mathrm{~m}$ in height, the crowns of which measured $2.65 \mathrm{~m}, 2.35 \mathrm{~m}$ and $1.70 \mathrm{~m}$.

\section{RESULTS}

\subsection{Biology}

\subsubsection{In the laboratory, rearing data and multiplication possibilities}

It is possible to maintain E. nigricornis in rearing conditions by means of each of the trials described above. It is easy to bring about laying on needles of maritime pine especially when these are arranged vertically (2nd trial) or naturally (4th and 5th trials). The female, straddling her support, carries out one or more incisions on the flat inside surface of the needle with her rostrum. Then she turns and deposits one or more eggs which are completely buried in the tissues of the needle. Laying has never been obtained apart from pine needles: P.nigra ssp. austriaca, $P$. sylvestris, $P$. halepensis are suitable for the genus Matsucoccus, a result comparable to those obtained with E. hebraicus [5]. However, a few results were obtained with an artificial support and sometimes some eggs are deposited in the synthetic green moss placed in the bottom of the rearing boxes ( 2 nd trial). The fecundity of adults collected in natural conditions varied between:

- 3 to 139 eggs (average 57 ), at $13-20{ }^{\circ} \mathrm{C}, 16$ hours of light with 9 couples;

- 15 to 48 eggs (average 29), at $25^{\circ} \mathrm{C}, 16$ hours of light with 4 couples;

- 2 to 11 eggs, at $15^{\circ} \mathrm{C}$, without light, with 3 couples. 
Table II. Averate times (max-min) of development in days of E. nigricornis, raised in different climatic conditions. The nymphs were fed on Anagasta kuehniella eggs.

\begin{tabular}{lccccc}
\hline & $13-20{ }^{\circ} \mathrm{C} 16 \mathrm{~h}$ & $15{ }^{\circ} \mathrm{C} 0 \mathrm{~h}$ & $20^{\circ} \mathrm{C} 0 \mathrm{~h}$ & $22.5^{\circ} \mathrm{C} 0 \mathrm{~h}$ & $25^{\circ} \mathrm{C} 0 \mathrm{~h}$ \\
\hline eggs & $15.5(14-16)$ & - & - & - & $9(8-11)$ \\
1st nymphal age & 6 & 9 & 7 & 3 & 4 \\
2nd nymphal age & 5.5 & 6 & 7 & 6 & 4 \\
3rd nymphal age & 6 & 13 & 7 & 5 & 3 \\
4th nymphal age & 4.5 & 15 & $36(32-34)$ & $30(24-28)$ & 7 \\
5th nymphal age & 12 & $57(55-60)$ & & $22(20-27)$ \\
Total (from 1 to 5) & $34(32-38)$ & & & \\
\hline
\end{tabular}

The average lengths of time for the development on eggs of A. kuehniella in rearing conditions are given in table II.

In rearing conditions, the nature of the food given to E. nigricornis is of significant importance. For example, beginning with 100 nymphs we obtained: 60 adults on M. feytaudi eggs, 20 on A. kuehniella eggs, 7 on A. kuehniella larvae, 3 on a semi-natural diet with a hen egg base (parafilm globule).

\subsubsection{In natural conditions, life cycle and number of generations}

The initial data were obtained by the method of direct counting, from 1967 to 1971 , at the sites indicated in table I. In each case the average density per tree of the nymphs and adults, years and sites put together, was noted (figure 1). The predator disappears from the trunks from December to 15th March, except for one exception, at le Dramont, which we will refer to later. Two significant multiplication periods can be distinguished, one in spring and an other in autumn. These correspond to two distinct generations, with another, hardly noticeable, one occurring between June and mid-August. Then, other data were obtained by indirect counting, from 03.03.1975 to 01.06.1976. These confirm that E. nigricornis multiplies at the rate of 3 generations a year (figure 2).

Hibernating takes place at the stage of the fertilised female (observations made at the stations of: Campaux, Treps, la Môle, Lambert). The females are then in a state of quiescence so that when selected they are able to lay in the laboratory at once. However, at le Dramont, on the coast, 24.01.1968, 8 males, 14 females and 140 nymphs were observed at all stages, which might indicate that during the winter a fourth generation could develop in

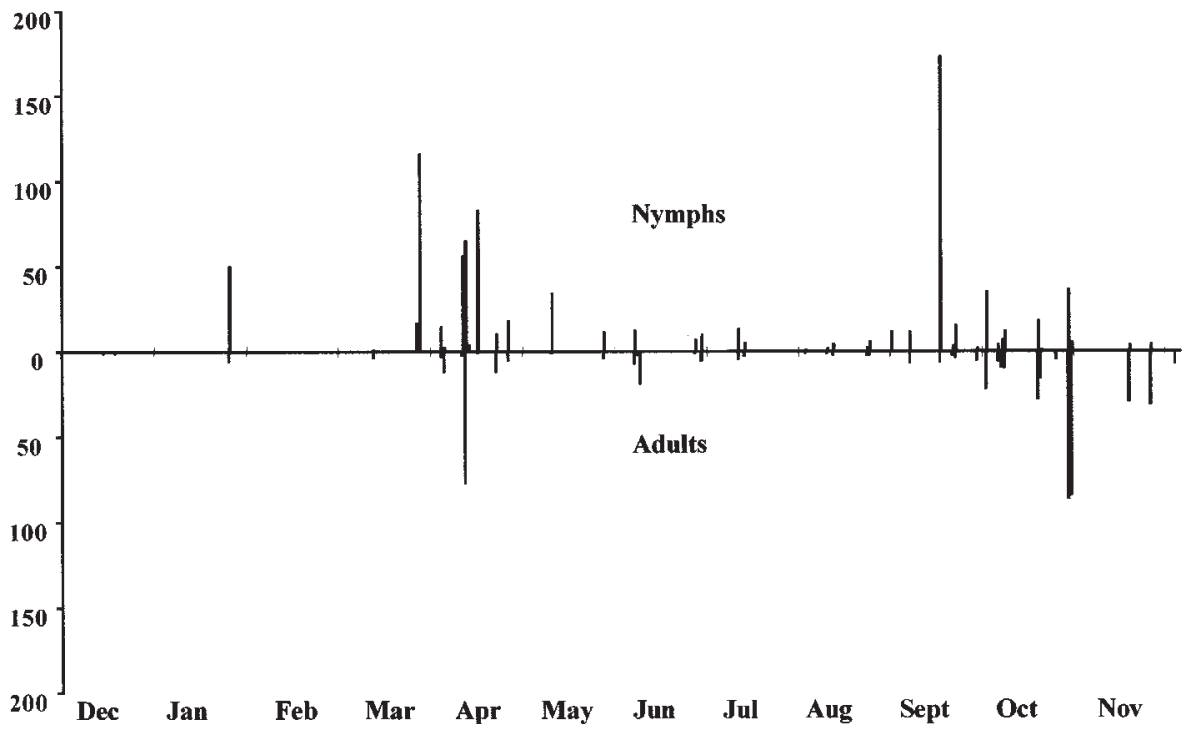

Figure 1. Evolution of the average density per tree of $E$. nigricornis (nymphs and adults), between 1967 and 1971, on 359 trees, in 9 sites in Maures and Estérel. 
RUSCAS
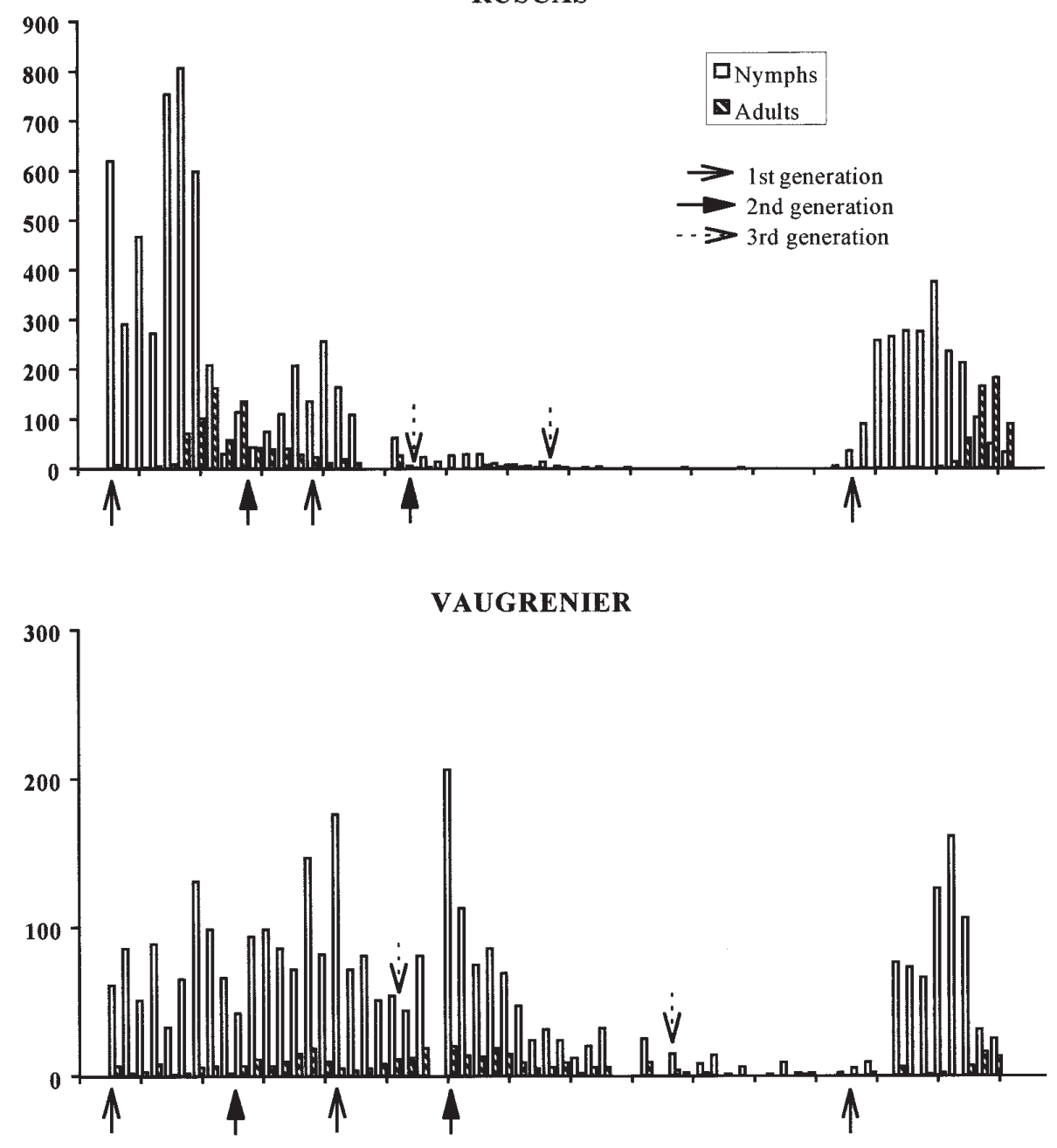

LAMBERT

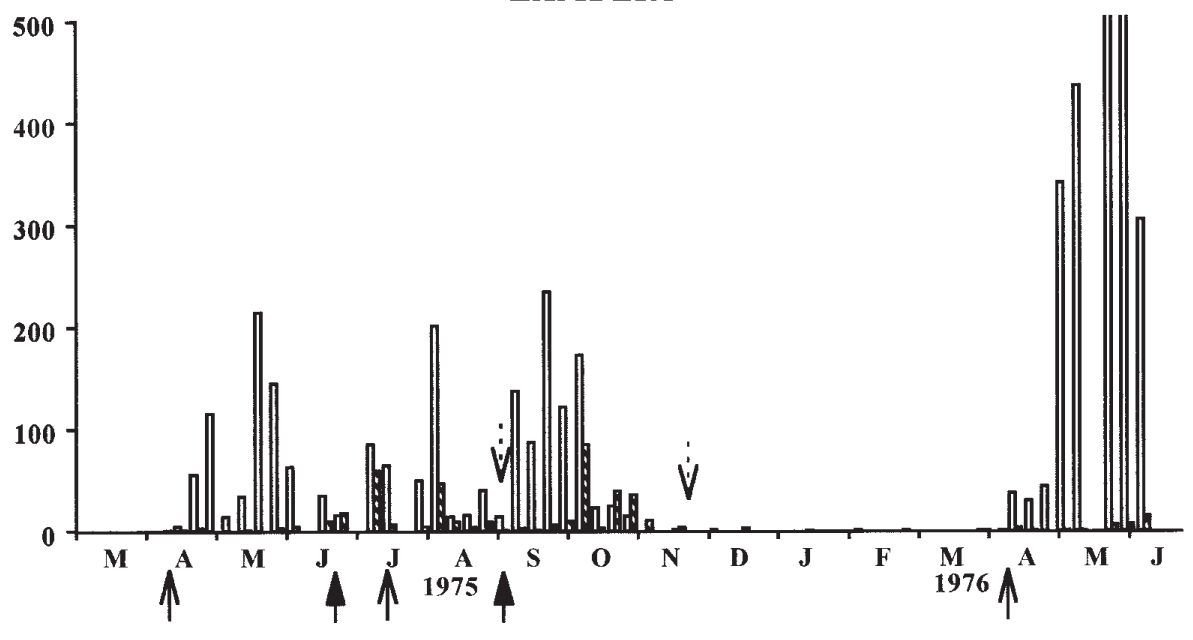

Figure 2. Evolution of captures of E. nigricornis (nymphs and adults), between 03.03.1975 and 15.06.1976, in 3 sites in Maures and Estérel. 
certain conditions. This latter point was confirmed at Vaugrenier from November until February 1975 where the four final nymphal stages were observed (figure 2).

\subsection{Population distributions}

In natural conditions, on maritime pine, the eggs of E. nigricornis are distributed in the needles. The 5 nymphal stages and the adults are found in the bark fissures. It is there that mating takes place.

\section{$\%$ needles with laying}

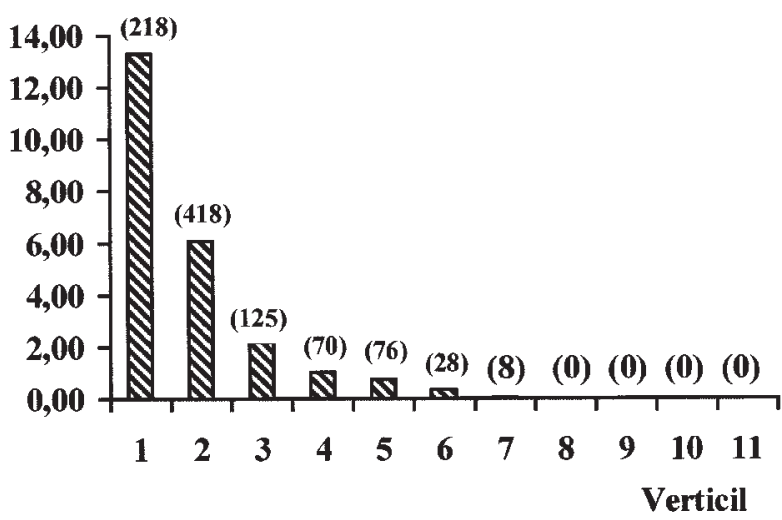

\subsubsection{Laying distribution in the crown}

A first crown consisting of 13745 needles had 217 needles with 649 eggs, more than $80 \%$ of which were to be found in the bottom third. Three other crowns had a total of 17123 needles, 261 of which contained 943 eggs. The later results are given in figure 3 for the distribution by verticil and in figure 4 for the distribution on the branches according to the age of the needles. Thus, in natural conditions, the eggs of E. nigricornis show the following distribution:

- According to the position in the crown, mainly in the first third of the crown ( $83 \%$ of the total), or on the

\section{Density of eggs / needle with laying}

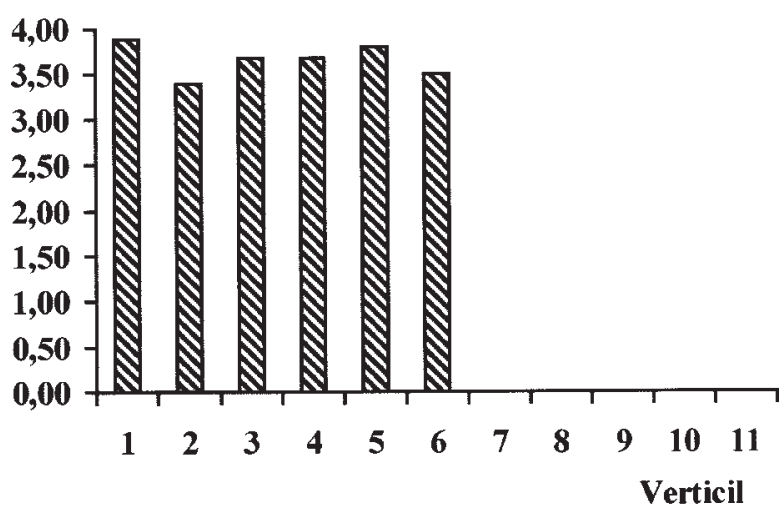

Figure 3. Vertical distribution (from bottom to top) of the population of E. nigricornis on the different verticils of the crowns of 3 trees; between parenthesis: number of eggs.

$\%$ needles with laying

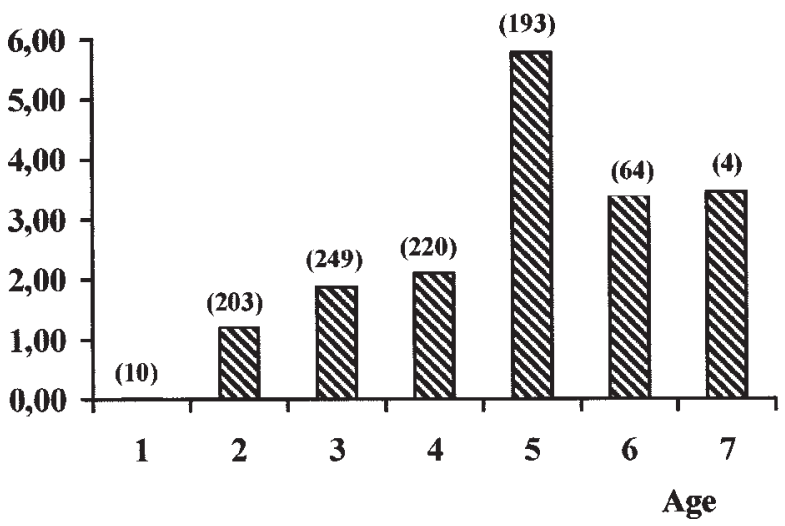

Density of eggs / needle with laying

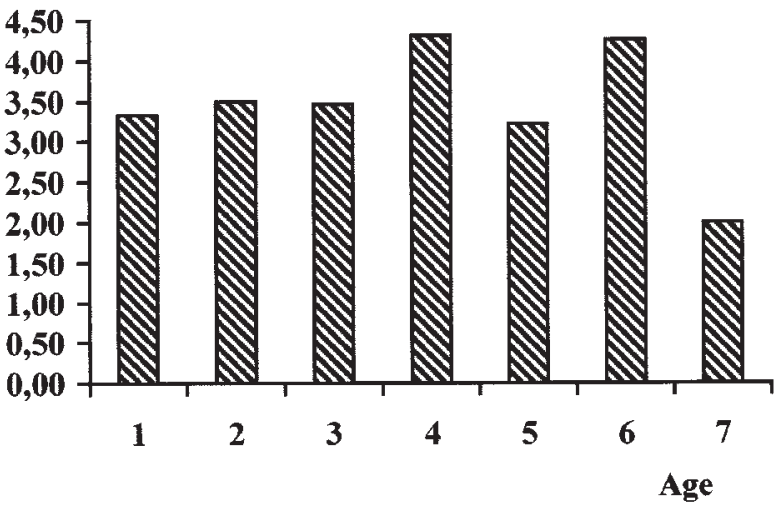

Figure 4. Distribution of the population of E. nigricornis eggs on the needles of branches according to their age; between parenthesis: number of eggs. 
first 3 verticils $(81 \%)$. The greatest number of eggs was observed on the second verticil (44\%). However, if the number of eggs is considered with reference to the total number of needles in each verticil which the females have available to deposit their eggs (relative $\%$ of needles with laying $=$ number of needle with laying / total number of needles $\times 100$ ), then the maximum is found in the first verticil. We observe a descending gradient from the bottom towards the top of the crowns. The reduced number of eggs on the first verticil would appear to be due to the fact that it has considerably fewer needles than the others. No laying was discovered above the 7 th verticil.

- According to the age of the needles, basically on needles aged between 2 and 5 (89\% of the total), the maximum being found on those aged 3 . The oldest needles near the trunk contain very few eggs, but if as previously the relative $\%$ of needles with laying is observed, these are the ones which receive most eggs. Consequently a horizontal gradient increasing according to their age is observed on the branches except on needles 5 years old.

\subsubsection{Distribution of nymphs and adults, on the tree spatial coincidence with its host M. Feytaudi}

The distribution of nymphs and adults of E. nigricornis was studied during the progression of M. feytaudi in the Estérel and long after its incursion into the Maures. In both cases, data were obtained on the predator-prey spatial coincidence.

\section{During infestation by $M$. feytaudi}

Out of 29 trees examined at la Bouverie (direct method) from 26.03 to $02.10 .1970,691$ nymphs and 48 adults were present on the trunk $(94.6 \%$ of the population) and 25 nymphs and 2 adults were on the branches of the crowns (5.4\% of the population). The rare predators collected on the branches were mostly 1st stage nymphs that had probably just hatched on the needles and were making their way towards the trunk fissures in order to look for food. The predator population (nymphs and adults) is therefore essentially on the tree trunks.

Out of 30 tree trunks, at la Bouverie (direct method) measuring 5-6 $\mathrm{m}$ in height, which were divided into 3 sections from the ground upwards, $90 \%$ (in relative value) of the total population were found in the second section, at a height of between $0.75 \mathrm{~m}$ and $2.50 \mathrm{~m}$. Other results were obtained at Vaugrenier, from 17.01.1974 to 21.03.1975, on 2 trees of $12 \mathrm{~m}$ and $9 \mathrm{~m}$ (indirect method, adhesive tapes placed every $50 \mathrm{~cm}$ ). The vertical distribution of the E. nigricornis specimens captured, all stages put together, is the same as on the previous trees. Thus, the predator population (nymphs and adults) is present in the trunk fissures with a depth of between 0.5 and $10 \mathrm{~mm}$ (figure 5). In addition, the number of specimens caught is not significantly different in the 4 geographical areas: $20.1 \%$ in the north, $28.6 \%$ in the south, $19.9 \%$ in the east and $28.1 \%$ in the west $\left(\chi^{2}\right.$ test $=2.57$, $\chi^{2}$ limit $=7.1,3 \mathrm{ddl}$, significance level $\left.\alpha=0.05\right)$. It was also possible to determine the spatial coincidence of the E. nigricornis and $M$. feytaudi populations. The results (figure 5) show that the populations of E. nigricornis nymphs and adults and $M$. feytaudi adults are distributed on the trunks between $1.50 \mathrm{~m}$ and $10 \mathrm{~m}$ on the first tree and $0.50 \mathrm{~m}$ and $8 \mathrm{~m}$ on the second. These examinations confirmed the absence of the predator and its prey at the base of the trunks where the bark fissures are more than $15 \mathrm{~mm}$ deep and on their extremities where there are not any fissures yet. However, the maximum number of E. nigricornis specimens captured at a height of approximately $6 \mathrm{~m}$ is not quite the same as that of the M. feytau$d i$ adults, i.e. a height of 5 and $3 \mathrm{~m}$ respectively. In fact, the population of the mobile stages of the pine scale is slightly displaced downwards and there is no correlation between the number of predators and the number of pine scale captured at different heights.

\section{After the invasion of $M$. feytaudi}

More than 15 years after the introduction of $M$. feytaudi, on a tree in a regeneration site, at Ruscas (83), the majority of the E. nigricornis population (72\%) were captured on the branches and the rest of the trunk (figure 6). Similarly, the majority of the M. feytaudi females $(64 \%)$ were captured on the branches. There was one apparent exception in the case of the male pronymphs captured between 30.09.1977 and $18.01 .1978,75 \%$ of which were captured in the trunk fissures. This is because these are used as shelters only by the male pronymphs, for their metamorphosis. The distribution of the E. nigricornis populations on the surviving tree in the regeneration site is thus totally different here. Finally, the sectorial and vertical distribution of E. nigricornis and M. feytaudi from 19.01.1978 to 12.04.1978 is higher on the western and southern sectors of the trunk and on the western sector of the branches (figure 7). The respective values of $\chi^{2}$ test are as follows: $12.32 ; 0.92 ; 24.60 ; 21.24$. These latter results again illustrate a very good spatial coincidence between the populations of the predator and those of its prey. In addition, in this case the total number of captures of E. nigricornis (y) is correlated to that of $M$. feytaudi $(x)$ in the following manner: on the trunk $y=0.4558^{\mathrm{e} 0.0069 x}$ (exponential adjustment) with $R^{2}=0.85$, on the branches $y=-5 \times 10^{-5} x^{2}+0.347 x-51.13$ (polynomial adjustment) with $R^{2}=0.98$. 

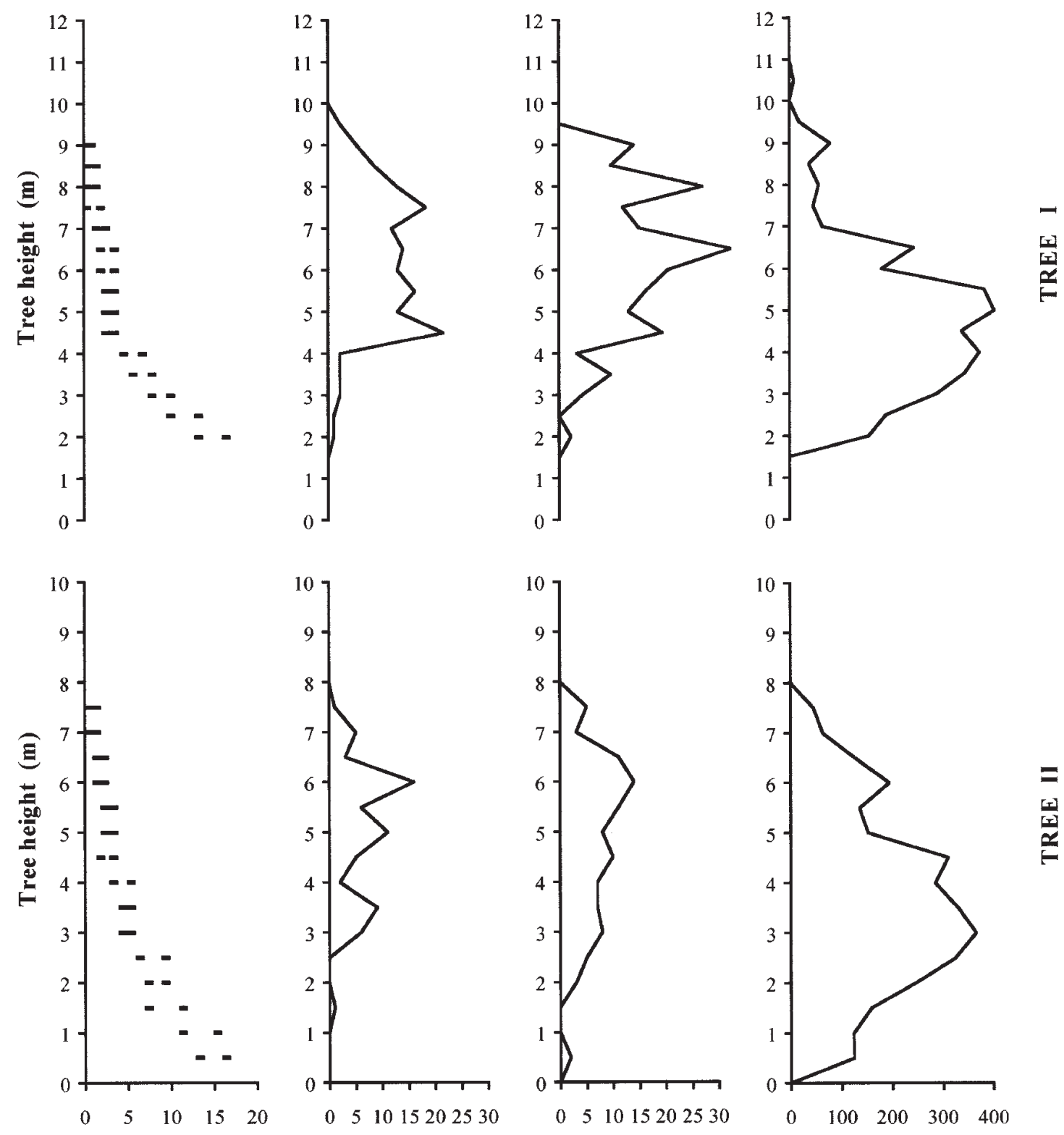

Depht of crack in mm Ny. E. nigricornis

Ad. E. nigricornis

Ad. M. feytaudi

Figure 5. Distribution of the captures of E. nigricornis and M. feytaudi between 17.01.1974 and 21.03.1975 on 2 trees (I = $12 \mathrm{~m}$, $\mathrm{II}=9 \mathrm{~m})$ at Vaugrenier compared with the depth (max, min) of the cracks in the bark of the trees.

\subsection{Number of populations}

The number of the predator populations was studied in various cases with different ecological conditions of M. feytaudi infestation: in the absence of the pine scale; on infested trees; on trees surviving in phloem areas damaged by pine scale stings with a definite reduction of its populations; on young trees resulting from natural regeneration following the destruction or removal of very infested populations; and finally in areas where $M$. feytaudi is endemic without causing any damage. 
E. nigricornis Nymphs

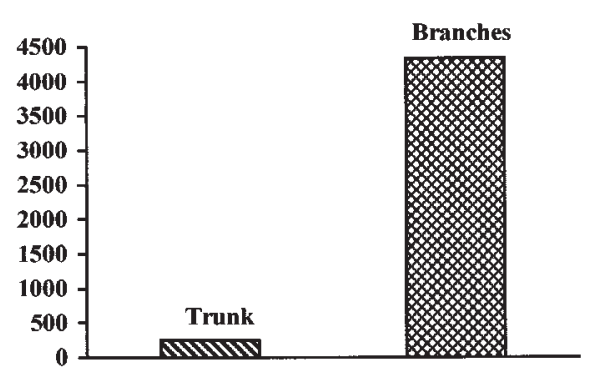

M. feytaudi male pronymphs

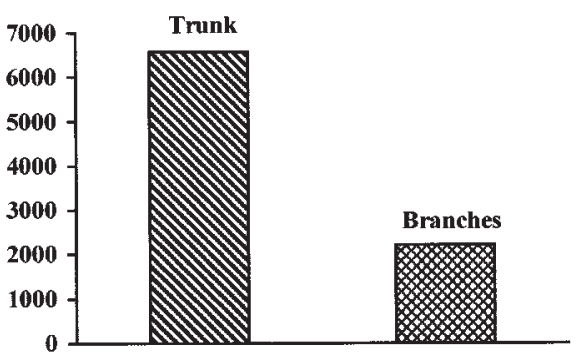

Figure 6. Distribution of the cap
tures of E. nigricornis and $M$. fey taudi on an "autoregulated" tree at Ruscas (83).

Figure 7. Sectorial distribution of the captures of E. nigricornis and M. feytaudi on the trunk and branches of an "autoregulated" tree at Ruscas (83).

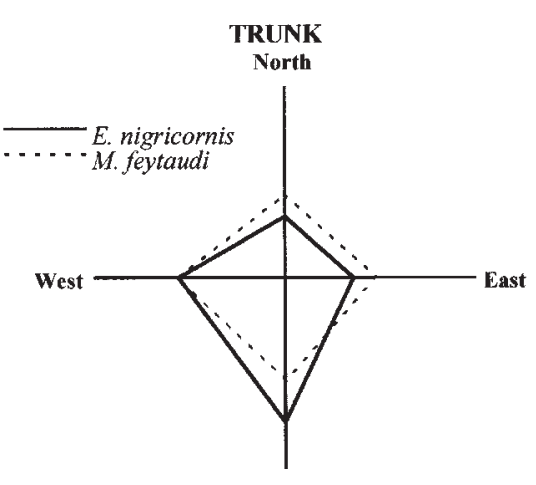

South
E. nigricornis Adults

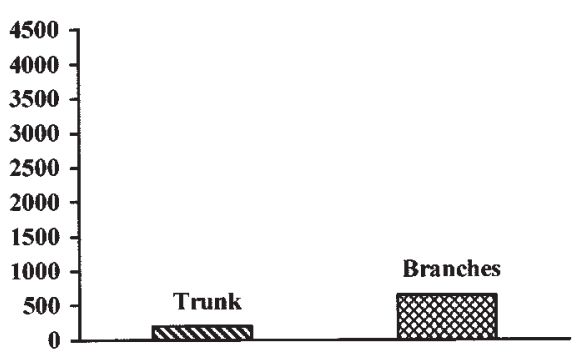

M. feytaudi Females
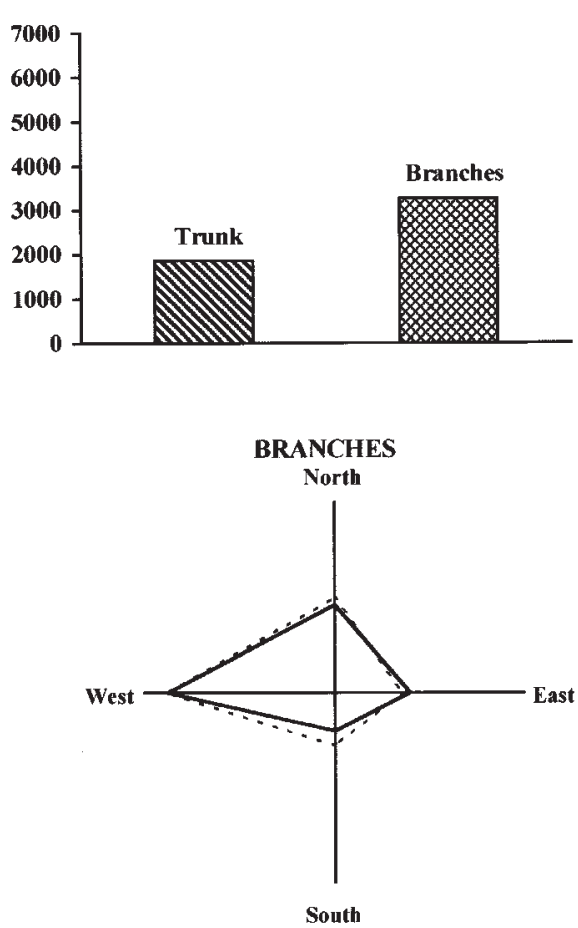

\subsubsection{In the absence of its host M. Feytaudi}

In 1968 , while $M$. feytaudi was spreading in the Maures, it had not yet reached Estérel. Thus, on more than 20 trees examined by the direct method, at Malpasset (Estérel) between 14.04 and 04.12, no Elatophilus was found. In Corsica, where the maritime pine was still free of $M$. feytaudi, adhesive tape traps were placed on more than 300 trees between 21.04. and 15.06.1976, in the forest of l'Ospédale, Aitone, Ghisoni, Bavella and no E. nigricornis were caught. Conversely, in Corsica, E. nigricornis was regularly captured on Pinus nigra Arn. ssp. laricio Poir.
Table III. Size of the density of E. nigricornis / tree in 9 stations of Maures and Estérel from 13.09.1967 to 21.10.1971.

\begin{tabular}{|c|c|c|}
\hline \multirow[t]{2}{*}{ Station } & \multicolumn{2}{|c|}{ Density E. nigricornis / tree } \\
\hline & Average & Maximum (date) \\
\hline les Dramonts & $35.00 \pm 27.76$ & $188(24.01 .1968)$ \\
\hline les Campaux & $12.58 \pm 9.43$ & 204 (10.04.1968) \\
\hline la Bouverie & $19.66 \pm 6.18$ & $235(15.04 .1970)$ \\
\hline Malpasset & $3.46 \pm 3.68$ & $41(24.11 .1968)$ \\
\hline les Cannebières & $13.22 \pm 4.18$ & $116(27.03 .1970)$ \\
\hline le Rouet & 24.0 & \\
\hline Forcalqueiret & $16.00 \pm 12.27$ & $26(18.09 .1968)$ \\
\hline le Treps & $7.81 \pm 6.76$ & $45(18.09 .1968)$ \\
\hline Notre Dame des Anges & $27.19 \pm 11.76$ & $218(25.10 .1967)$ \\
\hline
\end{tabular}


Table IV. Quantity of the populations of E. nigricornis and M. feytaudi in different stages of dieback of the trees.

\begin{tabular}{lcccccc}
\hline Symptom class & No of trees & \multicolumn{3}{c}{ Average no L2 M. feytaudi / $\mathrm{cm}^{2}$} & Average no E. nigricornis / tree \\
\hline & & $0.9-1.0 \mathrm{~m}$ & $1.9-2.0 \mathrm{~m}$ & $2.9-3.0 \mathrm{~m}$ & Gen. av. & $($ min.-max.) \\
0 & 12 & 1.0 & 1.4 & 0.3 & 0.9 & $15(1-45)$ \\
1 & 12 & 3.4 & 2.7 & 1.4 & 2.5 & $25(1-71]$ \\
2 & 12 & 1.7 & 1.0 & 0.4 & 1.0 & $18(1-51)$ \\
3 & 10 & 1.0 & 0.2 & 0.4 & 0.5 & $15(0-48)$ \\
\hline
\end{tabular}

\subsubsection{During the infestation by M. Feytaudi}

The number of E. nigricornis per tree (direct method) nymphs and adults together, varied from 0 to 180 ( $m=18.20 \pm 3.62 /$ tree) (tables I and III).

One might ask to what extent the density of E. nigricornis is related to the state of dieback of the trees (symptomatology) and to the level of infestation by the pine scale. In order to attempt to answer this question, we examined a sample of 46 trees by the direct method, at Bouverie, made up of 4 plots in various stages of dieback noted between 0 and 3 on which the density of pine scales was estimated (no L2 M. feytaudi $/ \mathrm{cm}^{2}$ ).

The results (table IV) show that the variations in the average number of E. nigricornis observed on the different samples are not significant.

However, during the invasion of the pine scale we were not able to establish an increase in the number of E. nigricornis in relation to the state of dieback of the trees. For this we should have taken other factors, into account notably the xylophagous which play an important part in the dieback of the trees and are the main reason for their disappearance. In fact, in cases where the trees which are attacked perish on a large scale because of the destructive action of the pine scale, there is a relation ship between the size of the E. nigricornis populations on the trees and the possibility that the trees will survive. Furthermore, we were able to confirm the hypothesis that there is an increase in the density of the predator during the invasion of the pine scale, by artificially increasing the population of $M$. feytaudi on the trunk.

At Vaugrenier (Estérel) other results were obtained by adhesive tape traps on 44 trees (2nd method) between 12.03.1975 and 27.04.1979. The evolution of the average number of captures per tree, all stages put together, is given in figure 8 . The total figure for all the stages put together was 7134 E. nigricornis captured, i.e. on average $2.64 \pm 0.5$ specimens per tree and per weekly collection (minimum 0 during the winter, maximum 15.33 on 18.04.1977). This stand has progressively disappeared as a result of infestation by $M$. feytaudi and one single tree remained alive on 27.04.1979. But during 1975 the average capture per tree was 98 predators on the 9 dead trees; later, during 1976, it was 181 predators on 21 trees that were still alive at the end of 1976, and 207 on the ones that survived beyond 1977 . This shows that the predator E. nigricornis did in fact contribute to the relative survival of the trees.

\subsubsection{After the invasion of M. feytaudi, on the surviving trees and on the regeneration trees}

The evolution in the size of the captures was determined (indirect method), particularly in a stand at Bagnols en Forêt (83). It is estimated that the introduction of the pine scale dates from 1967 and more than half the trees were still alive in 1994. Between 1972 and 1978 a considerable progression was observed in the number of weekly captures which increased from 0.57 per tree to 15.05 per tree (figure 9).

In addition, the density of E. nigricornis was evaluated in the forest of Lambert (83) in the Maures, on 30 trees in the regeneration area, which were, about ten years old in 1975. The results (figure 10) show that between 1975 and 1979 the average weekly density of captured predators per tree was $8.16 \pm 1.50$. This varied from 0 during the winter periods to 97.60 specimens per tree on 25.05.1976. In addition, on comparable trees at Ruscas (83) similar results were obtained between 1975 and 1978. These need to be compared with those previously obtained using the same method during the colonisation of $M$. feytaudi on adult trees in the forest of Vaugrenier (figure 10). The density of E. nigricornis is markedly higher on young regeneration trees and when M. feytaudi becomes endemic.

\subsubsection{In other regions where the pine scale is in an endemic state}

Data were obtained (indirect method) in other areas, on trees of the same size, where M. feytaudi is endemic without killing the trees. In the Landes, at Lagune du 


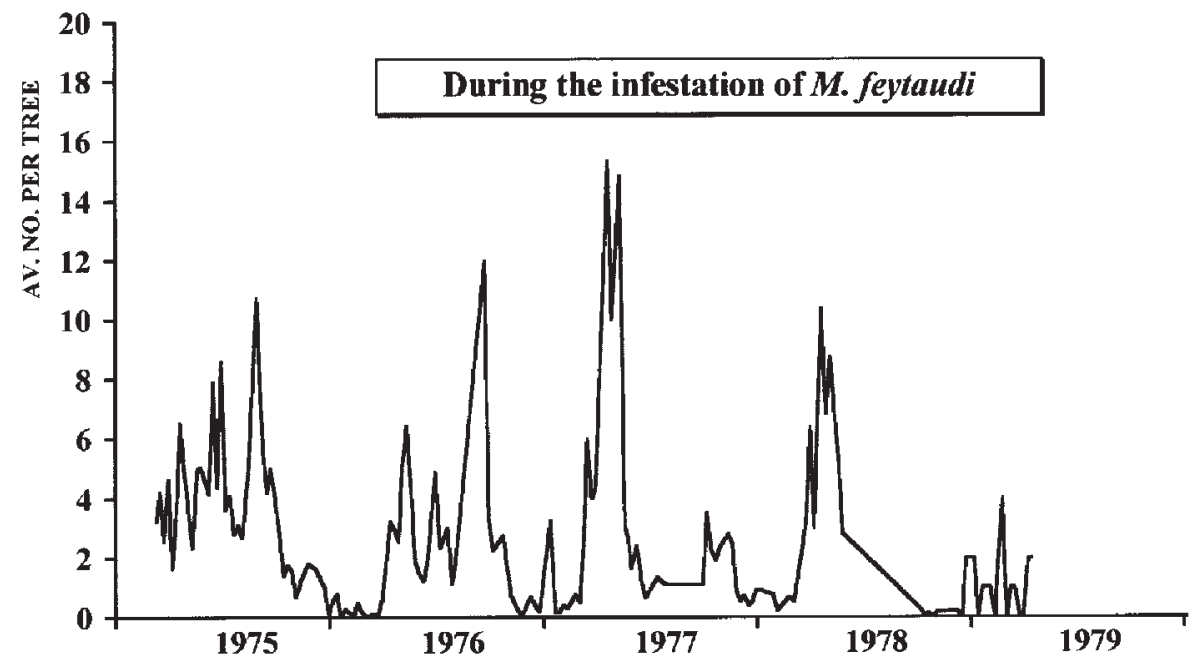

Figure 8. Evolution of the number of captures of E. nigricornis in a stand (trees that have disappeared) at Vaugrenier (06).

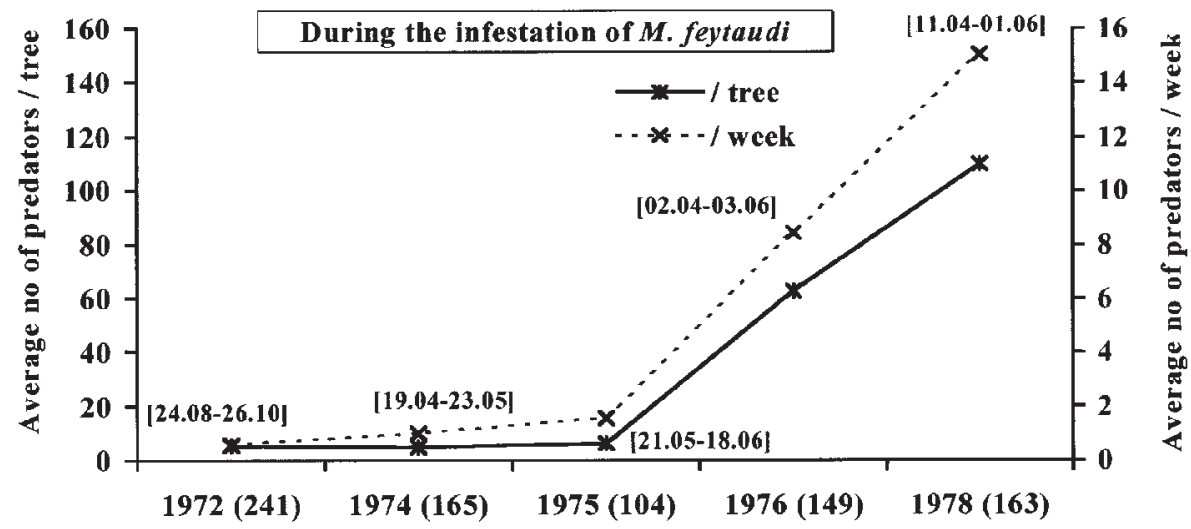

Figure 9. Progression from 1972 to 1978 of the average number of captures of E. nigricornis in a stand (trees that have survived) at Bagnols en Forêt (83); () No of trees involved; [] Dates of captures.

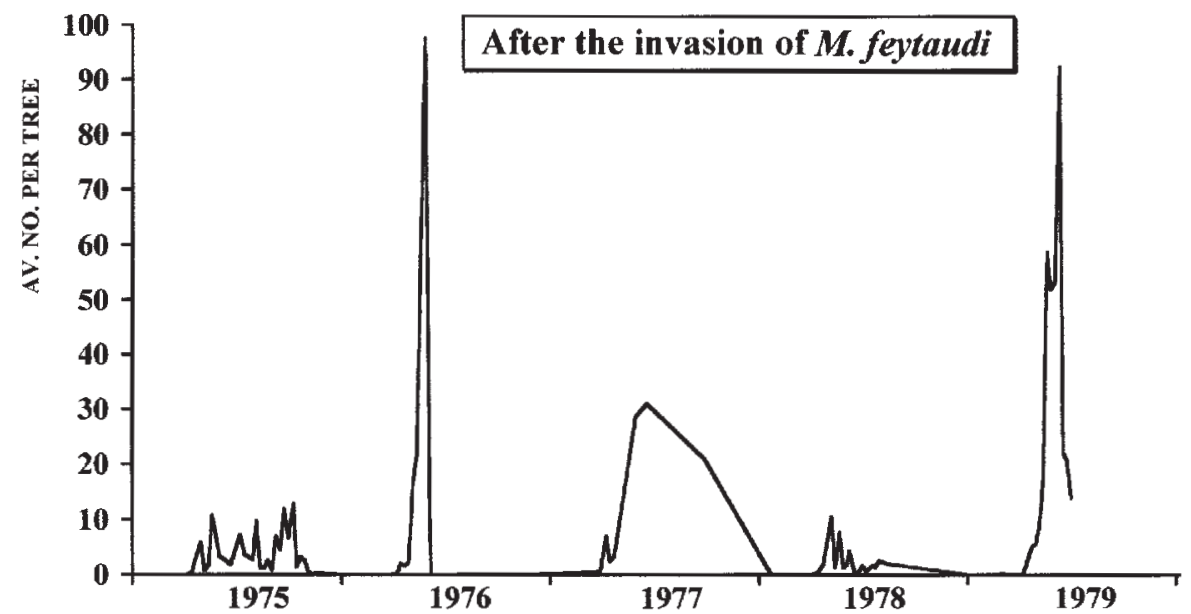

Figure 10. Evolution of the number of captures of $E$. nigricornis on regeneration trees at Lambert (83). 
Merle, the average density of E. nigricornis per tree of weekly captures was $0.45 \pm 0.14$ (minimum 0 on 07.01.1977, maximum $1.75 \pm 0.76$ on 08.06.1977). At Pierroton, a site near the previous one, an average of 2.17 (minimum 0 on 22.03.1978 and 29.03.1978, maximum $13.15 \pm 7.75$ on 31.05 .1978 ) was obtained. Furthermore, in the department of Ardèche at Vans an average weekly figure for captures per tree was $0.02 \pm 0.02$ (minimum 0 , maximum 0.75 on 30.05.1977 and 22.08.1977). In the latter stand 6 Scots pine $P$. sylvestris the same size as the maritime pine but with $M$. pini Green as the host of E. nigricornis were sampled under the same conditions as the maritime pine. The average density of the weekly captures per tree was 0.12 \pm 0.005 (minimum 0 , maximum $0.75+3.13$ on 18.08.1977). Traps placed in stands of maritime pine in Gard produced higher quantities of E. nigricornis (table $V$ ) in 3 cases.

\section{DISCUSSION AND CONCLUSIONS}

E. nigricornis produces on average 3 generations per year. The first, from the beginning of March onwards, coincides with the appearance of the adults and the laying of the pine scale which extends from the end of February / beginning of March to mid-April / end of May, depending on the site. The populations of E. nigricornis start to decline as the pine scale eggs begin to hatch [32]. At that point they consist essentially of the latest nymphal stages and adults. The second generation of the predator, between June and mid-August, coincides with the presence of pine scale larvae at the first stage. The third generation, from the end of August onwards, occurs at the same time as the passage of Matsucoccus from the 1 st to the 2 nd stage, which takes place in natural conditions at the bottom of the bark cracks. Using immunochemical techniques, it was shown that the predator was feeding on the eggs as well as the larvae or adults [15]; but the impact of the predator on the population of the prey will obviously be different according to

Table V. Average number of E. nigricornis captures in 4 stands in the Gard in 1978.

\begin{tabular}{lccc}
\hline Place & $\begin{array}{c}\text { Dates of } \\
\text { captures }\end{array}$ & $\begin{array}{c}\text { No of } \\
\text { trees } \\
\text { involved }\end{array}$ & $\begin{array}{c}\text { No of } \\
\text { predators } \\
\text { average / tree } \\
\text { average / week) }\end{array}$ \\
\hline Bessèges & $21.04-29.06$ & 22 & $0.00(0.00)$ \\
Col de la Baraque & $26.04-09.06$ & 35 & $59.46(9.24)$ \\
Les Bouzigues & $26.04-09.06$ & 59 & $27.28(4.34)$ \\
La Vernarède & $26.04-09.06$ & 67 & $27.21(4.20)$ \\
\hline
\end{tabular}

whether it attacks the eggs or a pre-laying female, just before the multiplication period of its prey.

On other models the temporal coincidence of the generations of the two species is quite different. Thus, Lusier in the USA studied the coincidence which exists between Elatophilus inimicus and Matsucoccus resinosae. The latter has two generations a year from June-July onwards and then from August-September onwards, periods when the two annual generations of the predator also appear. The two multiplication periods of the predators, which coincide with those of the pine scale, have been interpreted as a preference of E. inimicus for the eggs and the first stage larvae of $M$. resinosae [19]. In France, the temporal coincidence of E. nigricornis and Matsucoccus pini is different depending on the altitude. The pine scale has either one or 2 generations a year [31]. Thus, the impact of the predator on its prey also depends on their relative number of generations. In the present case study, E. nigricornis, which produces at least 3 generations a year, has a considerable advantage in being able to follow the multiplication of its host, which only multiplies at the rate of a single generation per year. In fact, almost all have the other harmful Matsucoccus several generations a year: 4-5 [2] to 6 [5] for M. josephi, 2 for M. matsumurae [6].

The E. nigricornis females deposit their eggs in isolation in the needles. Their distribution on the crown takes place according to a gradient starting from the trunk. These results lead us to put forward a hypothesis concerning the behaviour of the laying females. According to this hypothesis, after being fertilised in the deep cracks of the trunk, they make their way to the needles via the branches in order to lay. The likelihood of a needle receiving an egg depends therefore on its position with reference to the female's journey. The fact that no eggs were found on the current year's needles, which are found at the extremities of the branches, mostly excludes the possibility that the female might reach the extremities of the branches of the crown in order to deposit her eggs. These results do not agree with those of Sand [33]. He reports that E. nigricornis on woodland pine lays on the end parts of the crowns and on the young needles. However, for E. hebraicus the data established on two crowns of $P$. halepensis examined in Israel in August 1988 are completely compatible with our results [5, 25].

The distribution of the E. nigricornis populations in the cracks of the bark depends on how long $M$. feytaudi has been introduced. On standing forest trees, during the introduction of the pine scale, practically the whole of its population is confined to the trunk. However, when the pine scale becomes endemic, most of the predators are then found on the branches. This inversion of the trunk/branches distribution of E. nigricornis must be 
considered to be consequent to that of its host M. feytau$d i$. Thus, on the trunks of the surviving trees, or on regeneration trees, the phloem areas damaged by the pine scale stings become unfit for introducing further specimens. The result is a distinct reduction in the populations of M. feytaudi which develop mainly (up to 90\%) on the smoother parts of the trunk and especially on the branches. This phenomenon was described as autoregulation of the pine scale populations [33].

In Maures and Estérel the maritime pine stands were, as in Corsica, no doubt free of E. nigricornis before the introduction of $M$. feytaudi. However it is possible that the arrival of the predator on this pine species took place via its populations associated with $M$. pini on Scots pine situated some distance away in the hinterland. Thus, between 1964 and 1967, the stands were free of E. nigricornis despite being in a state of dieback, and it was thought that this would have to be introduced via the Landes massif (Riom and Gerbinot, personal communication). Since this study, we know that the sexual pheromone of the prey $[13,16]$ determines the attraction of the predators and especially that of E. nigricornis (Jactel and Menassieu, personal communication) but the distance between the two ecosystems was too great. On the other hand, in Corsica, since the Pinus nigra ssp. laricio is often mixed with the maritime pine, the recent presence of $M$. feytaudi should result in the immediate passage of E. nigricornis on to its "new host".

After the introduction of M. feytaudi, E. nigricornis multiplied and played a definite part in limiting the populations of its prey. Then, there was widespread destruction of the trees attacked due to the action of the xylophagous, and there is a link between the size of the E. nigricornis populations on the trees and the possibilities of tree survival.

After the invasion of M. feytaudi, in stands where more than half of the trees survived it was found that in 6 years the level of weekly captures had multiplied by 26. Finally, on regeneration trees which replaced the old stands that had been destroyed or felled, its population levels are 3 times greater. In this case, we established a good correlation between the number of predators and the number of pine scales. Another reason for the increase in the number of predators could be that on the one hand a time certain lapse was necessary for the multiplication of the predator on its prey and on the other hand that the prey population was maintained at a sufficiently high level. Whatever the explanation might be, we are unable to quantify the action of E. nigricornis on $M$. feytaudi directly, but there is no doubt that the relatively high number of predators on the trees which escaped the xylophagous and on the regeneration trees has a direct bearing on the size of the prey's populations and in the end on the survival of the trees. Thus, the survival of the trees to the present day in Maures, and Estérel could be explained by 3 factors which appeared one after the other during the year: the increase in the level of E. nigricornis populations; the decrease in the populations of $M$. feytaudi limited by the fissuration which appears progressively and due to the flow of resin resulting from the fixation of the larvae [33]; the presence of young trees originating from seeds which had undergone a very severe natural selection.

In areas where the pine scale lives in an endemic state the results are fragmentary and not comparable. Nevertheless, at Baraque Col, the number of weekly captures per tree is approximately 10, a figure which indicates that E. nigricornis is capable of reaching quite large population levels even when $M$. feytaudi has been in an endemic state for a very long time. In the other areas, in the endemic zone, E. nigricornis is present. The levels of the predators are apparently low, especially in the Landes but there is not sufficient data to reach a conclusion. In this area, from 1973 onwards, pine scale population levels have diminished. In 1977 they reached levels about ten times lower [33] and would thus be insufficient to maintain high densities of E. nigricornis in 1977 and 1978, but since we did not carry out investigations in 1973 we are not in a position to be absolutely sure. Unfortunately, the best-known Elatophilus predator species of Matsucoccus were almost always studied on models the host of which became harmful. This happens when it accidentally travels to other surroundings, on exotic varieties or in artificial plantations. This is the case of: $M$. matsumurae, native to Japan, in the NorthEast of China [20]; in the USA [20, 37] and in Korea [26]; $M$. josephi, native to Crete on $P$. brutia to the East of the Mediterranean basin [24]; M. pini in Europe [38] and in the Mediterranean basin [40].

In the laboratory, the best results in rearing E. nigricornis were obtained on M. feytaudi eggs, in rearing boxes containing a branch of maritime pine or a potraised seedling, in artificial climatic conditions resembling those of spring or autumn; in other words, by coming as close as possible to the conditions in which a good multiplication is observed in natural conditions. It would thus be possible to obtain 5-6 generations a year, a result comparable to those obtained with E. hebraicus [5].

However, for several reasons it is not possible to envisage large scale multiplication in the laboratory: no good replacement host is available; it does not take well to being handled with flexible pincers; the mortality rate during the embryonic development increases on isolated maritime pine needles (1st and 2nd trials) which dry out quickly; the mortality rate of the young nymphal stages 
is consistently very high; and, above all, no suitable substitute laying support has been found.

It was not possible to conduct an experiment with a localised increase in the level of its populations as a method of biological control. However, the corrugated cardboard trap method would allow easy transport of the predator to areas where it might be absent. In Maures, this operation might well have been beneficial, before 1967 , in order to facilitate its passage onto the stands of maritime pine at some distance from the stands of Scots pine found in the hinterland. Thus, the transfer of E. nipponensis in China, from Nanking to Soochow, over a short distance and in similar surroundings [6] was a success.

The transfer of several other species could be envisaged: E. hebraicus, E. inimicus, E. nipponensis. An attempt to import E. inimicus, native to the USA (Connecticut), was made in 1966 at the Campaux (Maures), apparently without success (Billiotti and Riom, personal communication). Seventy-nine E. nigricornis were installed, using the corrugated cardboard trap, in a stand of $P$. resinosae in Connecticut in October 1978 (Fabre, unpublished; Anderson, personal communication). However, such initiatives run the risk of polluting what is left of our natural ecosystems and our knowledge is still too fragmentary, particularly regarding taxonomy. Thus, E. nigricornis is thought to be the main predator of $M$. feytaudi in the South-East of France and the west of the Mediterranean basin. However, in Italy it would seem to be mixed with E. pini and even E. crassicornis $[8,9]$. Further east, it is E. hebraicus which is the main predator of $M$. josephi [5, 9, 25], and yet, E. nigricornis had been reported in Carmel [30]. Finally, other predators linked to the genus Matsucoccus could be studied and transferred. Thus in Italy on M. feytaudi, Rhyzobius chrysomeloides (Herbst) (Coleoptera Coccinelidae) [39] and to Japan, on M. matsumurae another ladybird beetle Harmonia axyridis Pallas was successfully introduced into Connecticut USA [21, 22].

Acknowledgements: Thanks are due to D. Schvester, director of the laboratory, J. Riom who gave me such a warm welcome into his team and B. Gerbinot, both of whom began this study before I arrived. I am grateful to those who counted, sorted, and measured with perseverance, the list of whom is long: O. Darricades, E. Furter, M. Hours-Bonnal, C. Seuzaret... My thanks also to M. Bariteau, present director, who together with D. Schvester encouraged me and helped with the production of this article and to M. Harrison who translated it.

\section{REFERENCES}

[1] Biliotti E., Riom J., Faune corticole du pin maritime: Elatophilus nigricornis Zett. (Hem. Anthocoridae), Ann. Soc. Entomol. Fr. 3 (1967) 1103-1108.

[2] Bodenheimeir F.S., Neumark S., The Israeli pine Matsucoccus, Kiryat Sepher, Jerusalem, 1955, 122 p.

[3] Carle P., Méthode d'obtention massive des pontes de Matsucoccus feytaudi Duc. (Coccoïdea, Margarodidae) par piègeage des femelles, Ann. Sci. For. 25 (1968) 57-68.

[4] Carle P., Le dépérissement du pin mésogéen en Provence : Rôle des insectes dans les modifications d'équilibre biologique des forêts envahies par Matsucoccus feytaudi Duc (Coccoïdea, Margarodidae), doctoral thesis, University of Bordeaux, Bordeaux, 1973, 174 p.

[5] Carmi E., Studies on the biology of Elatophilus hebraicus Péricart (Hemiptera Anthocoridae), a predator of Matsucoccus josephi Bodenheimer and Harpaz (Homoptera Margarodidae), M.S. thesis (in Hebrew), University Jerusalem, 1989, $71 \mathrm{p}$.

[6] Cheng H.Y., Ming W.J., Population dynamics and biological control of Matsucoccus matsumurae Kuwana (Homoptera Margarodidae) (in Chinese), Acta Entomol. Sinica 22 (1979) 149-155.

[7] Cheng H.Y., Ming W.J., Ge Q.J., Experiments and integrated pest control of Matsucoccus matsumurae Kuwana (in Chinese), J. Nanjing Technol. Coll. For. Prod. 1 (1983) 11-30.

[8] Covassi M., Poggesi G., Notizie sulla presenza e l'ecologia di Elatophilus pini Bär. in Italia (Heteroptera, Anthocoridae), Redia 69 (1986) 1-10.

[9] Covassi M., Binazzi A., Toccafondi P., Studi sugli entomofagi predatori di cocciniglie del Gen. Matsucoccus Cock. in Italia, I. Note faunistico-ecologiche su specie osservate in pinete della Liguria e della Toscana, Redia 74 (1991) 575-598.

[10] Covassi M., Binazzi A., Primi focolai di Matsucoccus feytaudi Ducasse nella Liguria orientale (Homoptera Margarodidae), Redia 75 (1992) 453-466.

[11] Daumal J., Méthode d'élevage de Cardiasthetus nazarenus Reuter (Hemipt. Anthocoridae) aux dépens des oeufs d'Anagasta kuehniella Z. (Lepidopt. Pyralidae), Ann. Epiphyties 19 (1968) 721-726.

[12] De Pontivy G., Contribution à l'étude de l'évolution dans les peuplements méditerranéens de pin maritime du dépérissement à Matsucoccus feytaudi Duc. et des biocénoses associées de ravageurs subcorticaux, doctoral thesis, University Marseilles St-Jérôme, 1978, 190 p.

[13] Einhorn J., Menassieu P., Malosse C., Ducrot P.H., Identification of the sex pheromone of the maritime pine scale Matscoccus feytaudi, Tetrahedron Lett. 31 (1990) 6633-6636.

[14] Fabre J.P., Mortalité dans les peuplements de pin maritime à la suite de l'introduction de Matsucoccus feytaudi Duc. en Italie, L'Italia Forestale e Montana 1 (1980) 39-41.

[15] Fabre J.P., Devergne J.C., Riom J., Étude des possibilités d'alimentation d'Elatophilus nigricornis (Hem. Anthocoridae) sur les larves de Matsucoccus feytaudi 
(Coccoidea, Margarodidae) au moyen de techniques immunochimiques, Ann. Soc. Entomol. Fr. 18 (1982) 31-42.

[16] Jactel H., Menassieu P., Lettere M., Mori K., Einhorn J., Field response of maritime pine scale, Matsucoccus feytaudi Duc (Homoptera: Margarodidae), to synthetic sex pheromone stereoisomers, J. Chem. Ecol. 20 (1994) 2159-2170.

[17] Jactel H., Menassieu P., Burban C., Découverte en Corse de Matsucoccus feytaudi Duc (Homoptera Margarodidae), cochenille du pin maritime, Ann. Sci. For. 53 (1996) 145-152.

[18] Jactel H., Menassieu P., Ceria A., Burban C., Regad J., Normand S., Carcreff E., Une pullulation de la cochenille Matsucoccus feytaudi provoque un début de dépérissement du pin maritime en Corse, Rev. For. Fr. 50 (1998) 33-43.

[19] Lusier S.J., Study of Elatophilus inimica Drake and Harris (Hemiptera, Anthocoridae) and its role in the natural control of the Red-pineScale, Matsucoccus resinosae Bean and Godwin, Thesis, University Massachussetts, 1965, 42 p.

[20] Mcclure M.S., Temperature and host availability affect the distribution of Matsucoccus matsumurae (Kuwana) (Homoptera: Margarodidae) in Asia and North America, Ann. Ent. Soc. America 76 (1983) 762-765.

[21] Mcclure M.S., Importing ladybird beetles to control red pine scale, Frontiers Plant. Sci. 39 (1986) 5-7.

[22] Mcclure M.S., Potential of the Asian predator, Harmonia axiridis Pallas (Coleoptera: Coccinellidae), to control Matsucoccus resinosae Bean and Godwin (Homoptera Margarodidae) in the United States, Env. Ent. 16 (1987) 224230.

[23] Mendel Z., Carmi E., Podoler H., Relation between the genera Matsucoccus (Homoptera: Margarodidae) and Elatophilus (Hemiptera: Anthocoridae) and their significance, Ann. Entomol. Soc. America 84 (1991) 502-50.

[24] Mendel Z., Schiller G., Biogeography of Matsucoccus josephi Bodenheimer and Harpaz in Crete and mainland Greece, Ann. Sci. For. 50 (1993) 325-416.

[25] Mendel Z., Carmi-Gera E., Podoler H., Assael F., Reproductive behavior of the specialist predator Elatophilus hebraicus (Hemiptera: Anthocoridae), Ann. Entomol. Soc. Am. 88 (1995) 856-861.

[26] Miller D.S., Park S.C., A new species of Matsucoccus (Homoptera: Coccoidea: Margarodidae) in Korea, Korean J. Plant Protection 26 (1987) 49-62.
[27] Ming W.J., Ge Q.J., Zheng H.Y., (Studies of some major predaceous natural enemies of Matsucoccus matsumurae (Kuwana)) (in Chinese), J. Nanjing Technol. Coll. For. Prod. 3 (1983) 19-29.

[28] Pericart J., Note taxonomique au sujet du genre Elatophilus Reuter, Description d'une espèce nouvelle et observations diverses (Hem. Anthocoridae), Bull. Soc. Entomol. Fr. 72 (1967) 52-60.

[29] Pericart J., Hemiptères Anthocoridae, Cimicidae, Microphysidae de l'ouest paléarctique, Masson et Cie Paris, 1972.

[30] Pericart J., Halperin J., The Anthocoridae of Israel, Phytoparasitica 17 (1989) 91-98.

[31] Rieux R., Contribution à la connaissance de la biologie et de l'écologie de Matsucoccus pini Green 1925 (Homoptera Coccoidea : Margarodidae), doctoral thesis, University of Provence, 1973, $97 \mathrm{p}$.

[32] Riom J., Gerbinot G., Boulbria A., Fabre J.P., Eléments de la bioécologie de Matsucoccus feytaudi Duc. (Coccoidea, Margarodidae) et de ses prédateurs dans le sud-est et le sudouest de la France, in : Colloque sur la lutte biologique en Forêt, Pont-à-Mousson 12-14 novembre 1969, Ann. Zool., Ecol. Anim., Suppl. (1969) 153-176.

[33] Riom J., Biologie et écologie des populations de la cochenille du pin maritime Matsucoccus feytaudi Duc (Coccoidea, Margarodidae) doctoral thesis, University Bordeaux I, Bordeaux, 1980, 263 p.

[34] Sands W.A., The immature stages of some British Anthocoridae (Hemiptera), Trans. R. Entomol. Soc. Lond. 109 (1957) 295-310.

[35] Schvester D., Observations générales sur le dépérissement du pin maritime dans les Maures, Rev. For. Fr. 6 (1967) 374-384.

[36] Schvester D., Matsucoccus feytaudi Duc et le «dépérissement» du pin maritime, in : Colloque sur la lutte biologique en Forêt, Pont-à-Mousson, 12-14 novembre 1969, Ann. Zool., Ecol. Anim., Suppl. (1971) 139-151.

[37] Stimmel J.F., First record of the red pine scale, Matsucoccus resinosae (Homoptera: Margarodidae) from Pennsylvania, Proc. Entomol. Soc. Wash. 83 (1981) 804.

[38] Siewniak M., Zur Morphologie und Bionomie der Kiefernborkensschildlaus, Matsucoccus pini (Green) (Hom Coccidea: Margarodidae), Zeitschrift für Angewandte Entomologie 81 (1976) 337-362. 